\title{
Biodegradation of palmarosa oil (green oil) by Serratia marcescens
}

\author{
"S. Mohanan, S. Maruthamuthu, N. Muthukumar, A. Rajesekar, N. Palaniswamy
}

Biocorrosion Division, Central Electrochemical Research Institute, Karaikudi, Tamil Nadu, India

Received 12 May 2006; revised 27 February 2007; accepted 8 March 2007; available online 20 March 2007

\begin{abstract}
Biodegradation of oil depends on the nature of the oil, the type of microbial community and a variety of environmental factors. Green oils are being used as consumer goods and as raw materials in industries such as food processing, pharmaceutical and cosmetic. Microbial contaminations of green oils have been the cause of degradation problems. Serratia Marcessens produced cytochrome oxidase, catalase, Dextrose, Lactose, Manose and sorbitol enzymes were the main reason for the degradation af palmarosa oil. Changes of colour and turbidity was also the evidence for green oil degradation by bacteria. More oxygen included protons $\left(\mathrm{O}-\mathrm{CH}_{2}\right)$ group was produced in the presence of bacterial species and the addition of oxygen took place during bacterial degradation of palmarosa oil. The biodegradation of palmarosa oil by Serratia marcescens have been carried out using High Performance Liquid Chromatography (HPLC), Fourier Transform Infrared Spectroscopy (FTIR) and Nuclear Magnetic spectroscopy (NMR) analysis. Carboxyl group present in the palmorasa oil is utilised as a sole carbon sources for the Serratia marcescens.

Key words: Biodegradation, green oil, palmarosa oil, serratia sp.
\end{abstract}

\section{INTRODUCTION}

Shogren (2003; 2004) Isinguzo (2005) reported that the biodegradation behaviour of polymerized green oils which were used in agriculture. The suitability of the respirometric BOD oxitop method for determining the biodegradability of oils in ground water using forestry hydraulic oils as model compounds (Kuokkanen, 2004). Liu-LJ (2002) studied the selective enzymatic degradation of poly and poly blend films. The proteins can degrade amorphous but cannot degrade crystalline materials. In contrast, Pseudomonas lipase can degrade both amorphous and crystalline. More literature have been discussing about the microbial degradation of hydrocarbon (Atlas, 1981; Kinney, 1968; Widdel, 1980). palmarosa oil is a pale yellow or pale olive liquid with a sweet, floral rosy odour and various back notes or top notes according to the quality and age of the oil. World production of green oil raised from $18 \times 10^{6}$ tones in 1960 (Karleskid, 1992) to 84 × $10^{6}$ tonnes in 1999 (Dabat and Lencon, 1999). This upward trend is mostly linked with the growing demand of importing countries like China and India with increasing population and standard of living. Microbial contamination of green oil has been the cause of degradation problems throughout the world for many years and more recently

\footnotetext{
*Corresponding author, Email: mohacecri@yahoo.co.in Tel.: 914565 227550; Fax: 914565227779
}

the frequency and severity of the cases appears to have been increasing dramatically (Gwenaella Bucas, 2002, Sevim, 1995, Zhengkai, 2004, Philp mercaria, 2004). In the present study Palmarosa green oil is selected which is much useful to us as cosmetic and the degradation study has been carried out.

\section{MATERIALS AND METHODS}

Palmorasa oil is collected from locally available market. Bushnell - Hass broth (Hi-Media), Nutrient agar and Serratia bacterial strain were used for the green oil degradation. The experimental system consists of $200 \mathrm{~mL}$ of BH broth, $5 \mathrm{~mL}$ of Palmorasa oil and $3 \mathrm{~mL}$ of bacterial strain. A control was identically maintained but without the inoculation of bacterial strain. To confirm the green oil degrading effect by the serratia sp, after 60 days incubation periods, one loopfull of culture from respective system were taken and strucked on nutrient agar plate and were incubated for $24 \mathrm{~h}$ at $37^{\circ} \mathrm{C}$ temperature and the bacterial counts were observed. After 25 days immersion, the residual green oil of the entire flask was extracted with an equal volume of dichloromethane. Evaporation of solvent was carried out in a hot water bath at $40^{\circ} \mathrm{C}$. The $1 \mu \mathrm{L}$ of the resultant solution was analyzed. The number of compounds in palmorasa oil and the degradation has 
been identified by using HPLC model (Shimadzu Japan model running 100\% methanol HPLC grade) and 254 nm wavelength at a flow rate of $1 \mathrm{ml}$ per minute. Elution, collection fractions, analysis and regarding of data are performed in an automatic analyser.

FTIR Por Elmer, UK make, Paragon 500 model was used to detect the functional group of the Palmorasa oil before and after degradation. The spectrum was taken in the mid IR region of $400-4000 / \mathrm{cm}$ with 16 scan speeds. The samples were fixed with $\mathrm{KBr}$ spectroscopic pure chloroform in the ratio of 1:100 and pellets were fixed in the sample holder and the analysis were carried out. NMR analysis was carried out using Perlin Elmer spectrometer to detect the protons of the nuclei in the Palmorasa oil was dissolved in deutrated chloroform solvent and tetra methyl silane was used as a reference standard various physical and biochemical tests were carried out from serratia bacterial sp.

\section{RESULTS}

Based on the colony morphology, physical and biochemical test, Serratia sp is a gram negative, rod shaped bacteria and grows under room temperature. The biochemical tests show positive to the citrate utilisation, voges prokauer, gelatine hydrolysis, cytochrome oxidase, catalase test and oxidation and fermentation test presented in the Table 1. Based on the biochemical tests, serratia sp produced enzymes like catalase, oxidase, textrase, lactose, mannose and sorbital. These enzymes are mainly involved in the degradation of green oil. The initial bacterial load was $4.8 \times 10^{5} \mathrm{CFU} / \mathrm{mL}$, while degradation the count

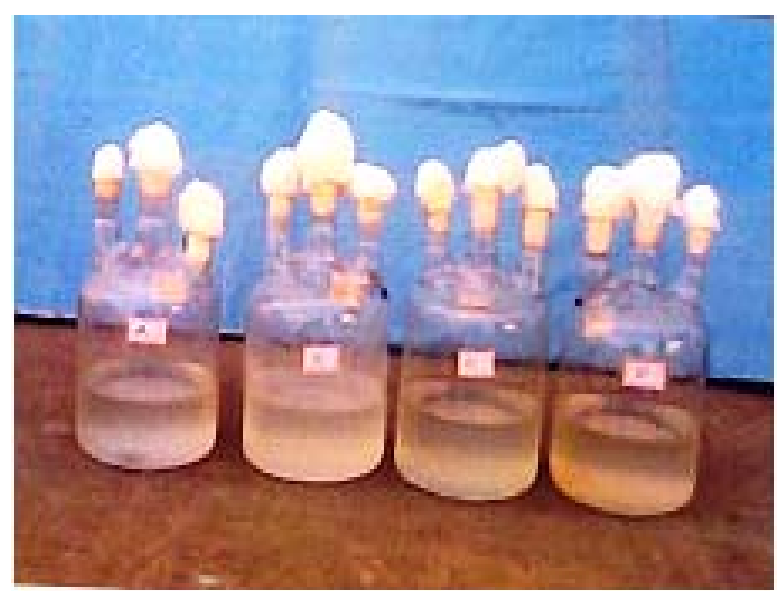

Fig. 1: Photomicrograph of before degradation of palmorasa oil increased to $2.0 \times 10^{6} \mathrm{CFU} / \mathrm{mL}$. It indicates that Serratia sp has taken energy from the green oil. Fig. 3 and Table 2 indicate the log value of the bacterial load.

The HPLC of palmarosa oil shows three peaks. It indicates that oil contains three numbers of compounds. In the Serratia bacterial strain inoculated system with palmarosa oil also shows three peaks but the peak height and percentage of area were changed. It indicates the palmarosa oil degraded by Serratia sp in Figs. 4 and 5.

Fig. 6 indicates that the IR spectrum of pure palmarosa oil in BH medium and Fig. 7 indicates the IR spectrum of depraded Palmarosa oil by bacteria. The pure palmarosa oil in BH medium shows the characteristic bands at 3354/ cm (OH group), 2967/cm and 2916/cm (C-H aliphatic stretch), $1740 / \mathrm{cm}$ and $1722 / \mathrm{cm}$ (C=O stretch for acid group), $1668 / \mathrm{cm}$ (C=C conjugated diene) $1442 / \mathrm{cm}$ and $1378 / \mathrm{cm}$ (C-H def in methyl group), 1233/cm, 1181/cm and $1094 / \mathrm{cm}$ (C=O stretch in C-O-C group), 996/cm, $830 / \mathrm{cm}, 777 / \mathrm{cm}$ and $743 / \mathrm{cm}$ sbstituted benzene. But presence of new peaks 3261/cm OH group. 1635/cm ( $\mathrm{C}=\mathrm{C}$ conjugated diene), 652/cm (Chloride position of the peaks and intensity of the peaks were varied. This is because of the bacterial degradation.

The NMR spectrum of pure palmarosa oil is shown in Fig. 8. Some major peaks at 0.3 chemical shifts indicate the presence of aliphatic protons. The other peaks at 4-6 chemical shifts indicate the presence of oxygenincluded protons $\left(\mathrm{O}-\mathrm{CH}_{2}\right)$ it may be due to the oil containing flavonoids group. But in the case of palmarosa oil with Serratia bacterial inoculated system the new peak was absent at 4-6 chemical shifts (Fig. 9).

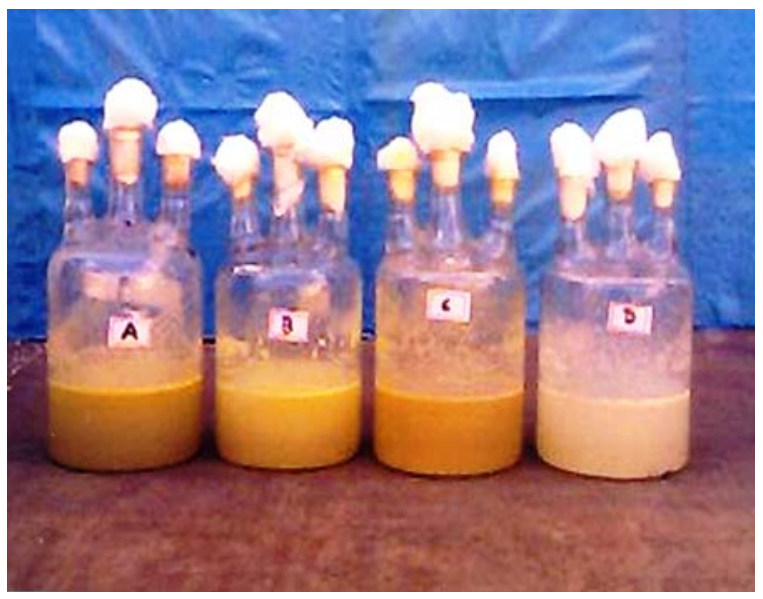

Fig. 2: Photomicrograph of after degradation of palmorasa oil 
Int. J. Environ. Sci. Tech., 4 (2): 277-281, 2007

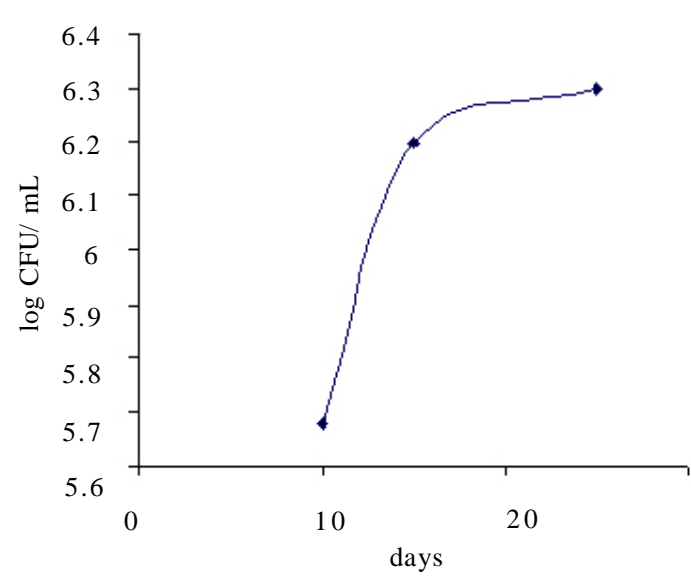

Fig. 3: Growth curve for the palmarosa oil in S. marcescens bacterial culture

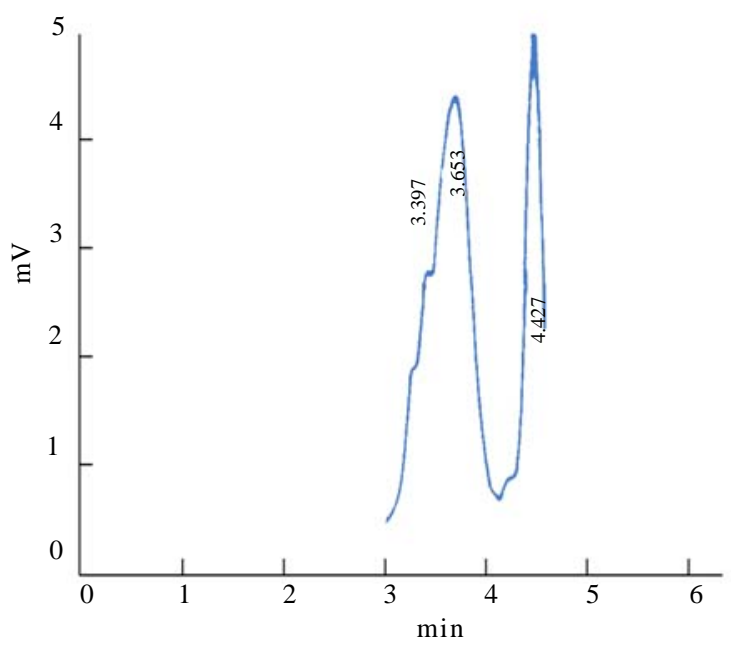

Fig. 4: HPLC spectrum of pure palmorasa oil

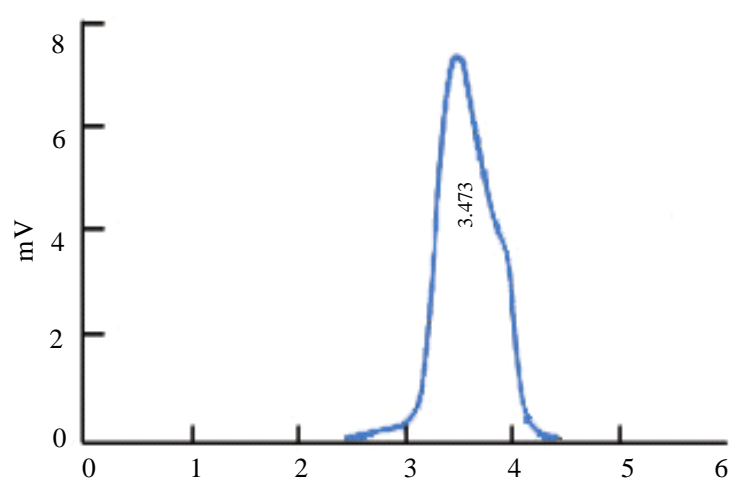

Fig. 5: HPLC spectrum of after 60 days inoculation with S. marcescens with palmorasa oil

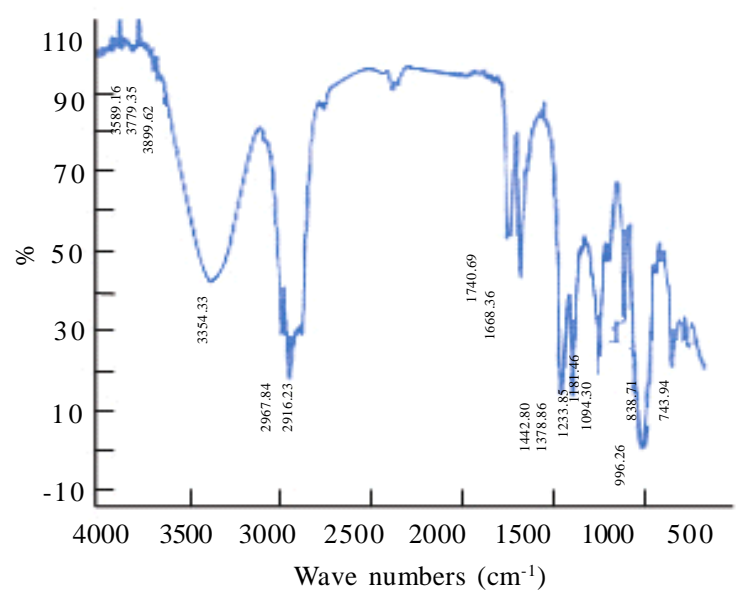

Fig. 6: FTIR spectrum of pure palmorasa oil

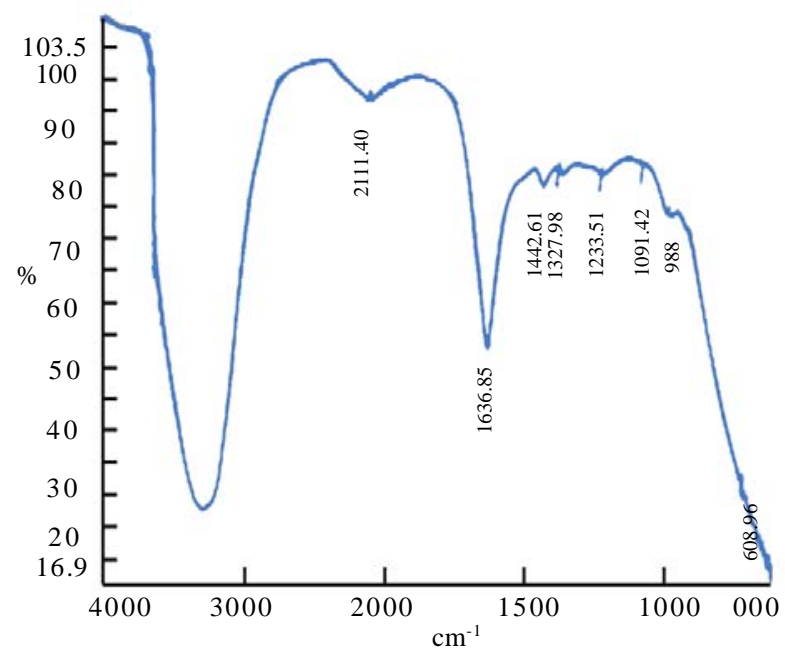

Fig.7: FTIR spectrum of after 60 days inoculation with S. marcescens with palmorasa oil

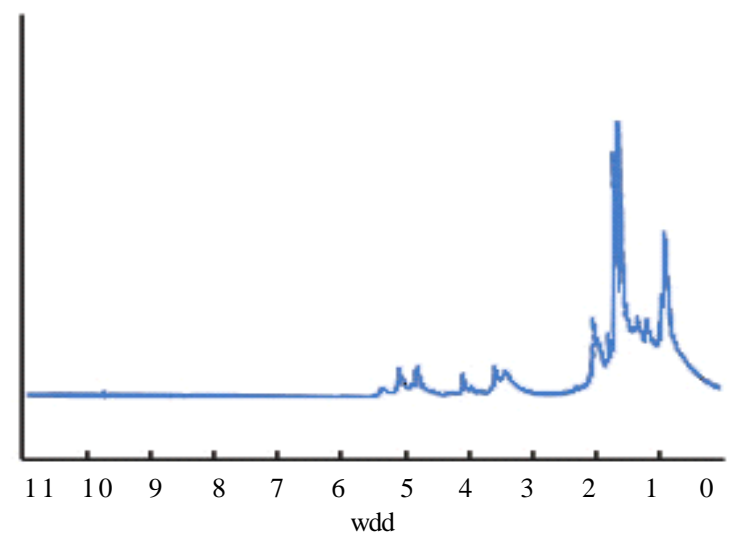

Fig. 8: NMR spectrum of pure palmorasa oil 


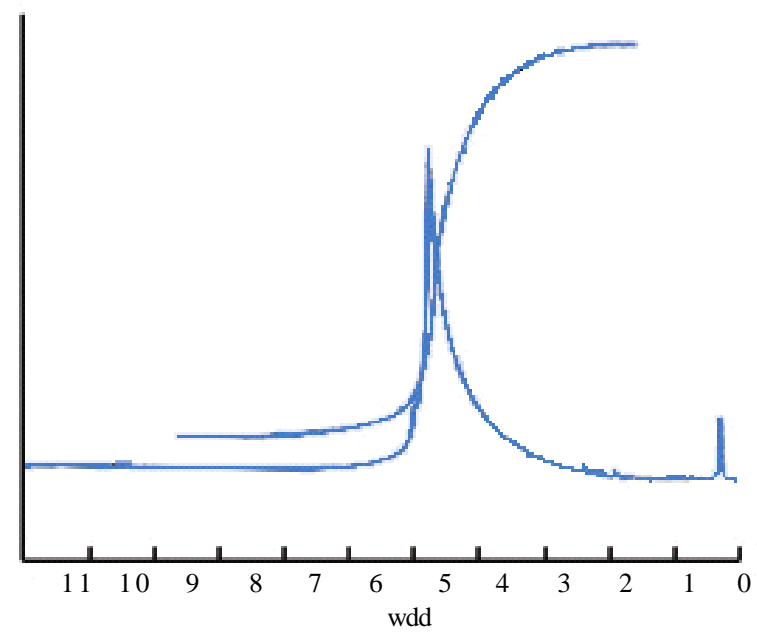

Fig. 9: NMR spectrum of after 60 days inoculation with S. marcescens with palmorasa oil

Table 1: Morphological, physical and biochemical tests for the Serratia marcescens

\begin{tabular}{|c|c|c|}
\hline Species No. & Test & Results \\
\hline \multirow{5}{*}{$\begin{array}{l}\text { Colony } \\
\text { morphology }\end{array}$} & Surface & Smooth \\
\hline & Pigments & - \\
\hline & Gram's reaction & - \\
\hline & Cell Shape & Rods \\
\hline & Arrangement & Single \\
\hline Spore & Endospores & - \\
\hline Production & Motility & + \\
\hline \multirow{6}{*}{$\begin{array}{l}\text { Physiological } \\
\text { Tests }\end{array}$} & Temperature & + \\
\hline & $25^{\circ} \mathrm{C}$ & + \\
\hline & $37^{\circ} \mathrm{C}$ & \\
\hline & $\mathrm{pH}$ & + \\
\hline & 5.7 & - \\
\hline & 6.8 & \\
\hline \multirow{12}{*}{$\begin{array}{l}\text { Biochemical } \\
\text { Tests }\end{array}$} & Growth on Mac Conkey Agar & + \\
\hline & Indole test & - \\
\hline & Methyl red test & - \\
\hline & Voges Proskauer test & + \\
\hline & Citrate utilization & + \\
\hline & Case in hydrolysis & - \\
\hline & Starch hydrolysis & - \\
\hline & Gelatin hydrolysis & + \\
\hline & $\mathrm{H}_{2} \mathrm{~S}$ production & - \\
\hline & Cyto chrome oxidase & + \\
\hline & Catalase test & + \\
\hline & Oxidation / Fermentation & + \\
\hline \multirow{4}{*}{$\begin{array}{l}\text { Acid production } \\
\text { from } \\
\text { carbohydrates }\end{array}$} & Dextrase & + \\
\hline & Lactose & + \\
\hline & Mannose & + \\
\hline & Sorbitol & + \\
\hline
\end{tabular}

It may be due to the bacterial degradation in palmarosa oil. The more oxygen-included protons (O$\mathrm{CH}_{2}$ ) group was produced in the presence of bacterial species. The addition of oxygen was took place during bacterial degradation of palmarosa oil. The effect of ferric hydroxide on the anaerobic biodegradation of green oil in fresh water sediments was studied (Lietal, 2004). Cavagnaro, et al. (1988) have reviewed the biodegradation of food oils and grasses. Several artricles speculate that soy oil should biodegrade more readily than mineral oil (Ticer, 1988).

Table 2: Enumeration of bacterial colonies (Serratia marcescens) during green oil degradation

\begin{tabular}{lccc}
\hline \multicolumn{1}{c}{ Sample } & $\begin{array}{c}\text { Biodegradation } \\
\text { periods (days) }\end{array}$ & $\begin{array}{c}\text { Bacterial } \\
\text { counts } \\
(\mathrm{CFU} / \mathrm{mL})\end{array}$ & $\begin{array}{c}\text { Log value } \\
(\mathrm{CFU} / \mathrm{mL})\end{array}$ \\
\hline $\begin{array}{l}200 \mathrm{~mL} \text { BH Broth }+ \\
5 \text { mL Palmarosa oil } \\
+3 \text { mL Serratia }\end{array}$ & 10 & $4.8 \times 10^{5}$ & 5.68 \\
$\begin{array}{l}\text { marcescens } \\
\text { bacterial culture }\end{array}$ & 60 & $1.6 \times 10^{\epsilon}$ & 6.20 \\
& 60 & $2.0 \times 10^{\epsilon}$ & 6.30 \\
\hline
\end{tabular}

Elimination or petroleum-based resin and reduced pigment requirements due to the light vehicle colour, should provide a competitively priced alternative to petroleum-based inks. These ink vehicles along with the commercial ones were subjected to biodegradation. The vegetable-oil vehicles degrade and more completely than commercial soy or mineral-oil based vehicles. Both mono and mixed cultures of microorganisms, which are commonly found in soil, were used. Greater increase in biodegration with time was observed in pure vegetable oil.

\section{DISCUSSION AND CONCLUSION}

Arthrobacter is capable of completely transforming added. Tyrosol to the corresponding 4-hydroxy phenylacetic acid and after $139 \mathrm{~h}$ of fermentation no traces of tyrosol can be identified G.Knuppa et al., (1996). In contrast, Bacillus ponilus was unable to completely biodegrade tyrosol over $139 \mathrm{~h}$.

Biodegradation of green oil in fresh water sediments exhibits self-inhibitory characteristics when it occurs under methanogenic conditions but not under iron reducing conditions. The basis of the protective effect of iron was investigated by comparing its effect on oil biodegradation rate the toxicity of oil amended sediments to those of clay and calcium, which reduce the toxicity of oil-derived long chain fatty acids by adsorption and precipitation respectively. This present work reveals that carboxyl group present in green oil is utilized as a sole carbon source for the Serratia species and the degradation took place as follows; 


$$
\mathrm{CH}_{2}-\mathrm{CH}_{2} \longrightarrow \text { Serratia sp }-\mathrm{O}-\mathrm{CH}_{2}
$$

The following observations have been made from the work reported in the present study

1. Based on the biochemical tests, Serratia sp. produced enzymes like catalase, oxidase, Dextrase, Lactose, mannose and Sorbital. These enzymes are mainly involved in the palmarosa oil degradation process.

2. From the HPLC, FTIR and NMR results indicate the palmarosa oil degraded by Serratia sp.

3. The present work reveals that carboxyl group present in the green oil is utilized as a carbon source for the Serratia sp. and the degradation took place.

\section{REFERENCES}

Cavagnaro, P.V., Kaszubowski, K.E., and Needles. H., (1988). Pretreatment limits for fats, oil and grease in domestic wastewater. Proc. $43^{\text {rd }}$ Industrial Waste Conference Purdue University, West Lafayette, Ind, 777-789.

Isinguzo, N.S., andBello, O.S., (2005). J. Food Agri. Environ., 3 (2), 299-301.

Kuokkanen. Vahaoja, T., and Valimaki lauhanen, R., (2004). Int. J. Environ. Anal. Chem. 4 (9), 677-689.

Liu, L.J, Li, S.M., Gareau, H., and Vert, M., (2002). Biomacro molecules Selective enzymatic degradation of poly (Llactide) and poly (Epsilon-Caprolactone), Blend films, 1 (3), $250-259$.

Shogren,R.L., Petronic Z., Liu, Z.S., Erthan, S.Z., (2004). American Chemical Society, 12 (3), 173-178.

Shogren, R.L., (2003). American Chemical Society, 225 (1) 57-67.

Ticer, J.M., (1988). Environmental factors in disposal, recycling and work place, proc. Symp. Soy oil, sect vii, ANPA, Reston, Va, 49-59.

Zhengkai L., Brjan A Wrenn, (2004). Anaerobic biodegradation, 38, 3859-3868.

\section{AUTHOR (S) BIOSKETCHES}

Mohanan, S., M.Sc., Ph.D., is a scientist in the Microbial Corrosion Group, Corrosion Protection Division, Central Electrochemical Research Institute, Karaikudi - 630 006, India. Email: mohacecri@yahoo.co.in

Maruthamuthu, S., M.Sc., M.Phil., Ph.D., is a scientist in the Microbial Corrosion Group, Corrosion Protection Division, Central Electrochemical Research Institute, Karaikudi - 630 006, India.

Email: biocorrcecri@gmail.com

Muthukumar, N., M.Sc., M.Phil., is a Senior Research Fellow in the Microbial Corrosion Group, Corrosion Protection Division, Central Electrochemical Research Institute, Karaikudi - 630 006, India.

Email: kumarmnagu@gmail.com

Rajasekar, A., M.Sc., is a Senior Research Fellow in the Microbial Corrosion Group, Corrosion Protection Division, Central Electrochemical Research Institute, Karaikudi - 630 006, India.

Email: raja76sekar@rediffmail.com

Palaniswamy, N., M.Sc., Ph.D., is a Dy. Director and Head, Corrosion Protection Division, Central Electrochemical Research Institute, Karaikudi - 630 006, India. Email: swamy23@rediffmail.com

This article should be referenced as follows:

Mohanan, S., Maruthamuthu, S., Muthukumar, N., Rajasekar, A., Palaniswamy, N., (2007). Biodegradation

of Palmarosa oil (Green oil) by Serratia marcescens. Int. J. Environ. Sci. Tech., 4 (2), 277-281 . 